\title{
Heterarchy: An Interorganizational Approach to Securing the United States Against a Pandemic Threat
}

\author{
By Diane Mars
}

United States public health and security capabilities are vulnerable to the magnitude and complexity of infectious diseases. Recently, human cases of a new $\mathrm{H} 7 \mathrm{Ng}$ influenza in China have underscored the unpredictability of outbreaks. This article analyzes the federal government's role in addressing an imminent pandemic threat from an organizational perspective, beginning with the Cabinet Departments of Homeland Security (DHS) and Health and Human Services (HHS), which jointly lead pandemic planning and response. This article recommends that these departments, their agencies, and international partners continue building and maintaining a heterarchy, the most optimal interorganizational structure for securing against and responding to a pandemic threat. This requires establishing clear, yet flexible responsibilities and shared systems, terminology, and tools. Given a hypothetical scenario in which a disease is introduced into the United States by a potentially infected foreign migrant entering through a maritime port of entry, current protocol and operations are promising. However, further heterarchical coordination is necessary to appropriately manage all plausible scenarios.

\section{Introduction}

The threat of pandemics poses a severe risk to the United States given today's interconnectivity. Homeland security and public health officials have maintained that the potential for a pandemic to occur is not a matter of if, but when (HHS 2012; CDC 2008; Pascoe 2006; White House 2005). So staving off catastrophe requires building and maintaining a preparedness infrastructure of unparalleled cooperation, vigilance, and participation. This article focuses on how federal departments and agencies in the executive branch organize their response to pandemic threats. The US Department of Homeland Security (DHS) currently leads in managing any pandemic threat in collaboration with the US Department of Health and Human Services (HHS), which is the medical response lead (Meeks 2005; GAO 2011). However, the two distinct Cabinet departments have been slow to manage their planning (GAO 2011; 2008). DHS and HHS Secretaries have repeatedly asserted that the federal government cannot handle such response efforts without involving partners across all sectors and levels of government (Denlinger 2007; Napolitano 2009).

This article argues that DHS and HHS should begin to establish and maintain a heterarchy, which is the optimal interorganizational structure for securing against and responding to a pandemic threat. First, this article provides background into the nature of infectious diseases and viruses. Second, it defines relevant organizational concepts. Third, it describes a hypothetical scenario in which a disease might be introduced into the United States by a potentially infected 
foreign migrant entering through a maritime port of entry. Finally, it offers recommendations for how DHS and HHS, and the agencies contained within them, can operate heterarchically to better address a future pandemic threat.

\section{Background: The Magnitude and Complexity of a Pandemic Threat}

\section{Problem}

Global susceptibility to pandemics stems from a number of complex factors involving space, time, zoology, and biology. Populations, and the diseases they carry, move rapidly across land, air, and sea (Tatem, Rogers, and Hay 2006). Transportation systems carrying people, food, and resources are ubiquitous and increasingly transnational (Honigsbaum 2012). The sharing of habitats with livestock and other animals has increased the risk of zoonotic ${ }^{1}$ bacteria and viruses, such as avian or swine influenza (ILRI 2012; WHO, n.d.). Virus vectors, such as those of migratory birds, and climatic and environmental changes also heighten urgency for action (Yu et al. 2009). New viral strains and diseases may evolve more rapidly than a country's defenses can be sufficiently mobilized. Influenza, in particular, is one of the greatest pandemic threats due its properties-respiratory routes, high mutation rates, and high-frequency contagion (Rodrigue 2013). Given a pandemic's potentially devastating consequences, including the loss of human life, government organizations must work with partners to detect and appropriately manage outbreaks to minimize morbidity and mortality. ${ }^{2}$

\section{Context}

\section{The Federal Government's Role}

The US federal government has an obligation to address and manage the response to a pandemic threat. Traditional governmental roles of policymaking, delivering services, and ensuring the continuous performance of essential func- tions have been critical to public health and security. Infectious diseases are widely acknowledged to be an issue of "shared concern" (Lemon 2007, xi), not just in the purview of the private health industry or medical academia. National defense against public health emergencies certainly qualifies as a public good according to public microeconomic theory.

The United States is making incremental progress toward integrated planning, detection, mitigation, and response to pandemic threats (HSC 2007). With every confirmed case or outbreak, the issue gains visibility, and national priorities are realigned. During the highly pathogenic avian influenza $\mathrm{H}_{5} \mathrm{~N} 1$ outbreaks in 2005, President George W. Bush outlined a firstever National Strategy for Pandemic Influenza, which called for "the leveraging of all instruments of national power, and coordinated action by all segments of government and society" (HSC 2005, 2). In 2012, President Barack Obama presented a firstever National Strategy for Biosurveillance, taking a more expansive approach toward responding to a class of threats, including not only emerging infectious diseases and pandemics, but also food-borne illnesses and bioterror attacks (White House 2012, ii). The issuance of directives and billions ${ }^{3}$ of dollars since the 2003 Severe Acute Respiratory Syndrome (SARS) outbreaks and $2009 \mathrm{H} 1 \mathrm{~N} 1$ swine influenza pandemic that affected the United States indicates the threat continues to be a national priority (White House 2007). In an example of Congressional consensus, the Senate and House passed the Pandemic and All-Hazards Preparedness Reauthorization Act of 2013 with unanimous and 370-28 votes, respectively (Burr 2013; Cohen 2013; US Congress 2013), with the President signing it into law on March 13, 2013 (HHS 2013). Whatever the decision or decree, the federal government's responsibility is to protect and safeguard its citizens and residents, and by extension, those of other nation-states-and to do so effectively. 
Table 1: Diseases and Viruses that may make Foreign Nationals or Migrants Inadmissible to the United States under the Immigration and Nationality Act

\begin{tabular}{|l|l|}
\hline \multicolumn{1}{|c|}{ Category } & \multicolumn{1}{c|}{ Disease or Virus } \\
\hline $\begin{array}{l}\text { I. Communicable diseases of public } \\
\text { health significance }\end{array}$ & $\begin{array}{l}\text { Chancroid, Gonorrhea, Granuloma ingui- } \\
\text { nale, Infectious leprosy, Lymphogranu- } \\
\text { loma venereum, Active tuberculosis, } \\
\text { Infectious syphilis }\end{array}$ \\
\hline $\begin{array}{l}\text { II. Diseases and viruses added by Presi- } \\
\text { dential Executive Order }\end{array}$ & $\begin{array}{l}\text { Cholera, Diphtheria, Infectious tubercu- } \\
\text { losis, Plague, Smallpox, Yellow fever, Vi- } \\
\text { ral hemorrhagic fevers (Lassa, Marburg, } \\
\text { Ebola, Crimean-Congo, South Ameri- } \\
\text { can), Severe acute respiratory syndrome } \\
\text { (SARS), Influenza (novel or reemergent) }\end{array}$ \\
\hline $\begin{array}{l}\text { III. Vaccine-preventable diseases of } \\
\text { concern }\end{array}$ & $\begin{array}{l}\text { Mumps, Measles, Rubella, Polio, Tetanus, } \\
\text { Diphtheria, Pertussis, Influenza type B }\end{array}$ \\
\hline
\end{tabular}

Source: Wasem 2011a, 3-4.

\section{Transnational Transmission}

Though no government could predict the specifics of an emerging pandemic threat with certainty, as President Obama has stated, "the threat will move rapidly and transcend boundaries and borders. So must our response" (White House 2012, i). It is imperative that countries stanch any influx of infections at internal and external points of entry (Wasem 2011a). Under certain conditions, developing countries may be at high risk for prevalence of emerging diseases (HSC 2007, 7). Compared to wealthier and industrialized countries, developing countries may not have the infrastructure, food, manufacturing, or health and safety standards in place to adequately prepare or protect the population at large (Oshitani, Kamigaki, and Suzuki 2008). In recent years, disease prevalence has occurred in various countries, from Haiti to China (Appendix 1). International air travel is a commonly accepted, plausible scenario for rapid global dissemination (Cooper et al. 2006). However, the Bush administration acknowledged that a "cross border flow" of "potentially infected... aliens attempting to cross between our ports of entry" could present challenges for the United States (HSC 2006, 78). Ports of entry are defined as government-desig- nated locations where persons, goods, and conveyances are screened (GAO 2008), and by their very nature, are conducive to person-to-person transmission.

A gap or lapse in detecting an infected person at any of the US's 329 ports of entry (CBP 2013; Wasem 2011a) could facilitate widespread infection of potentially millions at home, and billions throughout the world. As part of the US Code, the Immigration and Nationality Act outlines clear procedures and criteria for any foreign national who wishes to come into the United States and specifies health-related grounds under which one might be deemed inadmissible (Wasem 2011a). The HHS Secretary determines which diseases trigger inadmissibility under the Immigration and Nationality Act (Wasem 2011a), as shown in Table 1. Though the majority of US screenings and admissions occur along a land border and fall within the jurisdiction of Customs and Border Protection (CBP) (Wasem 2011a), a number of entry attempts occur at sea or maritime ports, which are monitored and managed by multiple organizations.

\section{Literature: Types of Organizational Structures}

In consideration of the pandemic 
threat, the possibility of disease transmission at ports of entry, and literature on organizational structure and the capacity to achieve organizational goals, ${ }^{4}$ this article defines three types of organizational structures: (1) a hierarchy, (2) a network, and (3) a heterarchy. The latter, which can be comprised of hierarchies and networks, is most relevant to institutionalizing effective public health and security responses to a pandemic threat.

\section{Hierarchies and Networks}

The first structure, hierarchy, has historically been the method of organization for public institutions (Kettl 2006; Senge 2006). It is the long-practiced structural arrangement in which individual units are layered with the most powerful on top and subordinates positioned underneath in a pyramid or a tree structure fashion. Hierarchy depends on authority (Kettl 2006) and "leading down" through the vertical organization (Senge 2006). Roles and chains of command are often clear-cut in a hierarchy, so it is prone to bureaucratic inertia (Kettl 2006; Senge 2006). For simple problems and operations, hierarchical government-and the specialization and division of labor it perpetuates-has worked, and may continue to work, reasonably well (Mahler 2009; Kettl 2008). Today, aspects of managerial governance remain hierarchical, such as formal decision making and authorizing processes (Considine and Lewis 2007).

A second type of structure, networks, have been increasingly used in recent decades to address public problems (O'Toole and Meier 2004). A network is a "nonrandom aggregation" of humans or units that intersect in latticed horizontal and vertical relationships, whereby "not all major components are encompassed within a single hierarchical array" (Stephenson 2009, 4; O'Toole and Meier 2004, 470; O’Toole 1997). A network typically includes hubs or nodes where interdependent or intersectoral components connect (Milward and Provan 2006). A network is likely more flexible and collaborative than a hierarchy (Kamarck 2002), and therefore more valuable (Milward and Provan 2006). A public network can include some combination of agencies, parts of agencies of the same government, links among units of different governments, or ties between organizations (O'Toole and Meier 2004). A network can span larger areas and marshal more diverse resources than a hierarchy, but because it can be diffuse and fixed in perceived spheres of influence, it can also be fragile (Milward and Provan 2006). During a period of "organizational reform" for public institutions in the 1990s and 2000s, governments main-

Figure 1: Hierarchy and Network

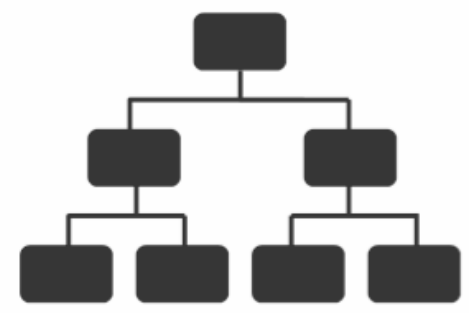

Hierarchy

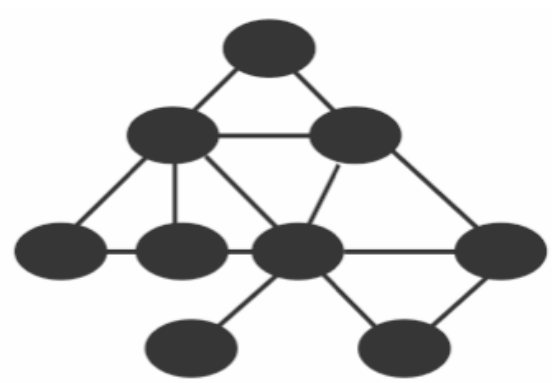

Network

Source: Author.

Note: The network illustrated is that of a mesh network, common in wireless communications and US national defense and intelligence (PR Newswire 2005). 
tained hierarchical structures while officials embraced networking mindsets and expectations (Considine and Lewis 2003, 134). But shortly thereafter, networks grew so large and "bewilderingly complex" that they required more managerial efforts than agencies could afford (O'Toole and Meier 2004, 471) and failed in execution. Many of today's policy problems, such as securing the nation against threats, involve highly complex and consequential managerial tasks, "multiple players," and unparalleled coordination (Agranoff and McGuire 2004, 509).

\section{Heterarchy}

The third structure, heterarchy, is a mega-state of connected networks or hierarchies (Stephenson 2009, 4). It is a relatively new way to conceptualize how very large, systematized, and goal-oriented networks work in the current age (Kleiner 2009). Whereas a hierarchy's focus is on "vested interest" and a network's is on "personal interest," a heterarchy's focus is on the collective good (Stephenson 2009, 6). First introduced in 1945 to describe the organization of the body's nervous system circuits for behavioral and purposeful activity (McCulloch), the concept was expanded decades later to refer to "the relation of elements to one another when they are unranked or when they pos- sess the potential for being ranked in a number of different ways" (Crumley 1995 , 3). A heterarchy differs from a network in that it: (1) is more expansive in size; (2) is more systematized and less prone to the vagaries of perceived influence or power; (3) has one specific policy goal; and (4) has more dynamic connections. These attributes make heterarchies well suited for intergovernmental responses to large public problems.

A heterarchy can be aligned for purpose and social responsibility, and its structure enables greater participation among its members at both the individual and organizational levels (Stephenson 2009). In a hierarchy, action follows authority, routine policies, and clear protocol. In a network, an organization might work with preapproved partners within first, second, or third degrees of connection. However in a heterarchy, accountability is "lateral," and paths unfold dynamically in response to the context of a problem (Stark 2001, 21; Crumley 1995). This is often facilitated by technological drivers-such as the Internet, Web 2.0 platforms, and other user-generated tools-and by "concrete collaborative planning," or strategic design (Hellingrath and Küppers 2011, 1). Heterarchical action may be intermittent, but members "sense and respond" together (Stephenson

Figure 2: Heterarchy

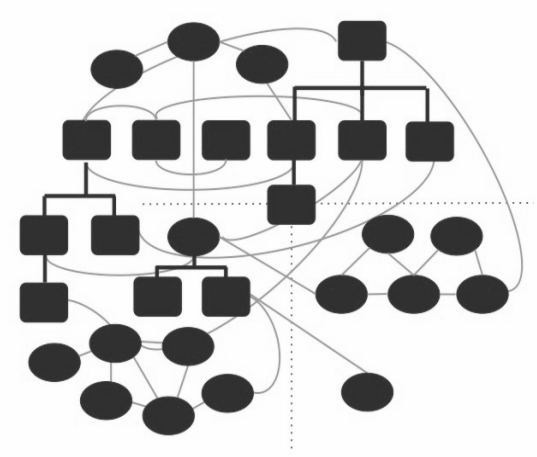

Source: Author. 
2009, 6). The terms networks and heterarchies are sometimes used synonymously because current definitions of heterarchy still vary (Dawson 2009; Kleiner 2009; Wachhaus 2008). However, a heterarchy can combine the best of both networks and hierarchies by possessing some of their qualities (Reus 2009), e.g., the diverse collaboration of networks or the managerial decision making of hierarchies. Further, a heterarchy is useful where members must operate in "an environment of institutional uncertainty" (Stark 2001, 21). For these reasons, a heterarchy is an ideal structure for government entities and their partners in planning and preparing for a potential pandemic.

\section{Analysis: Operating Heterarchically to Secure the Nation Against a Pandemic Threat}

\section{At the Cabinet Department Level}

Given its size, systemization, and adaptability, a heterarchy is an ideal structure for governments to adopt in preparing for pandemics. The relative importance of entities within a heterarchy changes and responds to extrinsic shifts that continually re-rank priorities (Crumley 1995), and this adaptation can help match the speed and unpredictability of diseases and viruses. Heterarchical behavior can potentially lead to efficiency gains through collective leverage. When prioritized and maintained, a heterarchy may enable entities such as Cabinet departments DHS and HHS to overcome silos or identify interdependencies amid different missions and methods. Security functions are numerous: domestic, regional, and international preparedness planning; disease intervention strategies, such as quarantine, containment, and modeling; and priority setting for access to limited-availability health care resources (Lemon 2007). During a time-sensitive crisis, miscommunication or poor coordination could spiral into systemic breakdowns. Any ambiguity in priorities, responsibilities, or informa- tion could jeopardize the response-and human lives. Leveraging existing departmental capabilities requires engaging with partners across multiple cross-functional areas that cannot be managed by one person, team, agency, department, or government.

\section{Gradual Alignment Through Evaluation and Communication}

Federal departments are moving toward more heterarchical operations, but progress remains slow. In 2005, DHS was given top authority to manage influenza pandemics, though HHS was declared primarily responsible for the medical response (Meeks 2005). Some questions were raised about the two distinct executive Cabinet departments' "unique relationship" and potentially conflictual "chain of authority" (Meeks 2005), particularly given that DHS had been founded only three years prior in response to $9 / 11$ (DHS 2013b). Years later, the concerns about the departments' organization and performance remain valid. In its 2011 assessment of the handling of the $2009 \mathrm{H} 1 \mathrm{~N} 1$ influenza pandemic, the Government Accountability Office (GAO) recommended that the Homeland Security Council (HSC) direct National Security Staff to work with DHS and HHS (2011). The GAO's 2012 assessment found "key deficiencies in information sharing among government agencies, which could obstruct a coordinated federal response to a possible outbreak" (Pavgi 2012). Through evaluation and assessment, DHS and HHS are only beginning to align operations and improve internal, external, and lateral accountability among their partners.

Sharing communication tools and frameworks is a challenging yet necessary first step toward collaboration. Strides have been made in information systems, e.g., the development of a Homeland Security Information Network and a BioWatch system, which DHS leads and the Centers for Disease Control and Prevention (CDC) helps operate (DHS 2013a; Mosquera 
2006). However setting expectations and establishing standards, particularly among DHS's and HHS's most important partners, are necessary to have a shared understanding of the problem. The US Pandemic Severity Index was developed in 2007 to provide meaningful categorical triggers, but HHS has deemed it "inadequate... during the initial stage of response" to the $\mathrm{H} 1 \mathrm{~N} 1$ pandemic (2012, vii). Another example of a coordination failure is that United States' five-point index does not match that of the World Health Organization's (WHO) six-point scale (HHS and DHS, n.d.; Reuters 2009). Incompatibility may create more ambiguity for governments, their employees, and their citizens across the globe. The WHO has attempted to develop a shared nomenclature for multiple diseases, but health officials have been publically criticized for failing to clearly define what the word pandemic even means (Altman 2009; WHO 2011c). With basic terminology so ambiguous and open to misinterpretation, opportunities exist for US departments and their agencies to help establish a solid foundation upon which parts of the heterarchy can be more reliably situated.

\section{At the Agency Level}

\section{Wide-ranging and Systematized Information Sharing}

With the US levels of government so vast and needs so decentralized, detecting an infected person will likely occur at the outermost reaches of government structures (Lemon 2007). A heterarchy's intricate communications may help members to identify, isolate, and control a disease before it becomes widespread (HHS, n.d.). Preparedness and emergency responsibilities are highly decentralized among thousands of jurisdictions and professions. Any one of these entities, which have historically operated with so little central guidance that their "extensive consultation and cooperation" may be required by law (Jenkins 2006, 320), will likely be the first line of defense against an emerging pandemic threat. Accordingly, so-called child agencies like CDC that lie within a larger parent department like HHS, have been directed to actively engage with "architecture of Federal, State, local, tribal, territorial, and private capabilities" as a top priority (US Congress 2013; White House 2012, 2).

In a heterarchy, agencies are both compelled and motivated to systematically share information. This is especially significant at the heterarchy's peripheries because higher-level decisions can be simultaneously made, such as whether pandemic alerts should be raised or quarantines should be extended geographically. As agencies depend more on stakeholders for information, such "situational assessment" operations become more sophisticated, e.g., complex event processing, geographic information systems, and predictive analytics (FEMA 2012; Stojanovic 2011; ESRI 2013; Yu et al. 2009). Such systems reinforce heterarchical thinking across boundaries and may facilitate greater accuracy, timeliness, and consistency in a given scenario.

Scenario: Transmission Threats at Sea Ports and Migrant Interdiction

The beginnings of heterarchical thinking and cooperation can be observed in a specific scenario whereby a disease or virus, introduced by a potentially infected foreign migrant entering through a maritime port, is contained through interdiction. Migrant interdiction is one functional operation that plays a critical role in safeguarding the United States against pandemics through the stopping, screening, and quarantining of migrants who attempt to enter the country illegally by sea. Interdiction is one of DHS's core capabilities, and it is defined as the interception and prevention of movement of a prohibited person or commodity (FEMA 2012).

Within DHS, the US Coast Guard (USCG) runs Alien Migrant Interdiction Operations as one of eleven maritime mis- 
sions. On an average day, the USCG performs 28 safety and environmental examinations of foreign vessels (USCG 2011b), so it is frequently the first point of contact for those trying to enter the country via maritime ports. Though its task is to enforce immigration law at sea, the contact means there is heightened risk of disease transmission if just one infected migrant were undetected or processed without adequate precaution. Though luck has helped play a role in keeping the United States safe so far (Schwartz and Schwartz 2010; CBO 2005; WHO 2010a), coordination between the USCG, CDC, and others is promising because it illustrates how multiple agencies can manage transmission incidents successfully.

In the last few years, there have been a number of high-risk outbreaks and interdictions that required the USCG, CDC, and other agencies to work together heterarchically. The five countries from which the most undocumented migrants originate via maritime ports are: Haiti, the Dominican Republic, the People's Republic of China, Cuba, and Mexico (USCG 2011c, 2011d). Three epidemics and one pandemic in the past 10 years have had points of origins from three of these countries: (1) the H1N1 influenza pandemic in 2009 from Veracruz, Mexico; (2) the SARS epidemic in 2003 from Southern China; (3) the $\mathrm{H}_{5} \mathrm{~N} 1$ influenza epidemic in 2003 from China; and (4) the cholera outbreaks in 2010 from Haiti (Appendix 1). Agencies jointly monitored and collaborated in the responses. For example, the 2010 Haitian cholera epidemic following the catastrophic earthquake coincided with a surge in Haitian interdictions (Wasem 2011b). Four other federal agencies besides the USCG are responsible for Haitian migrants: CBP, which has 20 quarantine stations and health officials on call for all ports of entry (Wasem 2011b; GAO 2008); Immigration and Customs Enforcement; US Citizenship and Immigration Services; and the Department of Justice's Executive Office for Immigration Review (Wasem 2011b). Thus, multiple officers at multiple seaports had to work vigorously to maintain a network of communication lines for each migrant screening and case (Wasem 2011b, 17).

In high-risk scenarios, agencies can choreograph heterarchical responses that are systematic yet flexible. SARS and the $\mathrm{H}_{5} \mathrm{~N} 1$ both originated from China and, during the outbreak periods, there have been increases in the number of migrants interdicted by USCG from China (2011c). In a hypothetical transmission scenario, a man from Fujian Province, China might travel to the United States via a small shipping vessel with SARS, $\mathrm{H}_{5} \mathrm{~N} 1$, or another undisclosed disease or virus. The USCG must rely on its own and other reliable surveillance systems to interdict the boat when it reaches within 200 miles of the US shore (USCG 2010). The man is undocumented and has no US visa, and therefore cannot demonstrate whether he has been vaccinated against certain vaccine-preventable diseases, as detailed in Table 1. $\mathrm{He}$ is not eligible for an Immigration and Nationality Act waiver (Wasem 2011a) from the other health-related grounds for inadmissibility because he is not: a husband, unmarried son, or father of a US citizen; an alien lawfully admitted for permanent residence; or an alien issued an immigrant visa (Wasem 2011a). If the man discloses that he needs medical attention-or a USCG officer suspects that is the case-the officer communicates the incident appropriately through a number of alert systems, such as the Treasury Enforcement Communications System or the Homeland Security Information Network (Wasem 2011a). There are numerous, rigorous medical examinations by the CDC's panel physicians or civil surgeons (Wasem 2011a) and its Division of Global Migration and Quarantine, which is responsible for managing infectious diseases among immigrants, refugees, international travelers, and other mobile populations that cross international borders (GAO 2008).

In an example of flexibility and 
coordination, the USCG may either be supported by, or may support, US Department of Defense forces by law (DTIC 2012, xi). Similarly, USCG and CBP officers have statutory responsibility "to aid in the enforcement of quarantine rules and regulations" (Wasem 2011a, 7). If there are many potentially infected migrants, or if the disease has spread, coordination with the naval services of nations may lead to the establishment of task forces in international waters to provide vaccines, antivirals, and other assistance to multinational mariners of commercial vessels as they transit into or out of maritime chokepoints and sea lanes (Rodrigue 2013). This coordination undoubtedly requires a broad range of equipment, which can be facilitated through assistance from partner entities. The USCG or CDC may also exchange information with appropriate extragovernmental bodies, including the WHO, the Food and Agriculture Organization of the United Nations, and the World Organization for Animal Health (USAID 2012). They may also communicate with dozens of foreign governments, including Chinese authorities, who may request information to stanch the spread in Fujian. Further, these agencies have other obligations and similar threats to monitor and prepare for, such as chemical, biological, radiological, and nuclear agents, which would involve defense agencies and potentially result in geopolitical situations or foreign policy consequences (DTIC 2012). This scenario demonstrates the complexity of disease transmission and the adaptability and effectiveness of heterarchical operations.

\section{Findings and Further Considerations}

Intergovernmental collaboration is moving toward heterarchical collaboration. In outbreaks over the past few years, contamination and death were minimized. However, much remains to be done. The fact that no SARS "super-spreaders," or people who infect more than 10 others, made it to the United States from China in 2003 was a purely a matter of luck (Schwartz and Schwartz 2010). Luck may also have played a role in staving off $\mathrm{H}_{5} \mathrm{~N} 1$ since 1997 (CBO 2005). According to a post-H1N1 pandemic statement by WHO Director-General Dr. Margaret Chan, "This time around, we have been aided by good luck ${ }^{5}$ " (2010). With so many different public entities-each carrying with it varying levels of hierarchical bureaucracy, network formations, protocols, and missions-it may be easy for mistakes or miscommunication about the threat to occur. Evolving roles, relationships, and peripheral considerations emphasize the need to establish a heterarchy, one that is strategically cultivated and nurtured to help most, if not all, participants, run smooth operations and deal with the high probability that someone will make a mistake (Kamarck 2002).

US departments and agencies should invest in shared tools and resources, which are fundamental to any public partnership. There are essential benefits to coordinating with international bodies, including those countries that might not be as prepared against a pandemic threat, such as Vietnam or India, and specialized international agencies, such as the WHO. A steady flow of assistance is already in place; the United States provided technical assistance, commodities, and logistical or financial support to 39 of 60 countries that had $\mathrm{H}_{5} \mathrm{~N} 1$ on three continents (HSC 2007). However rather than depend entirely on intelligence from the WHO, one of the most important players in global health and pandemic-related activities, the United States can further invest in communications and systems to control diseases and viruses in real time. It is this real-time interconnectivity between countries and regions across the globe that helped control the 2003 SARS outbreak (Lemon 2007). As the United States' vulnerability partially depends on other countries' and the WHO's successes, the federal government must take steps to identify and 
invest in the parts of the heterarchy that could lead to further optimization.

Threats to security are compounded when resources are scarce, but heterarchical collective leverage may be a salve. Having been criticized for decades for large deficit spending, the federal government's automatic spending cuts, or sequestration, would "significantly diminish" the ability to protect Americans from infectious diseases and lead to a dangerous health risk (APHA 2013, 1). From CDC's budget alone, $\$ 450$ million may be cut (California Healthline 2013; Food Safety News 2013). Trusted heterarchical partners may achieve economies of scale and reduce costs without drastically sacrificing quality of service. In a heterarchical model, future budget restrictions may force lean departments and agencies to innovate and collaborate further.

\section{Conclusion}

Heterarchies, along with the hierarchies and networks that can comprise them, are the most optimal structures to stave off a pandemic threat and potentially catastrophic loss of life. Such interorganizational responses are becoming increasingly beneficial to governments in situations that require unparalleled coordination between multiple levels of government and society, particularly if federal budget spending cuts occur. A case for heterarchies can be made in the containment of diseases and viruses at US maritime points of entry. Migrant interdiction and detection comprise one type of operation that helped to minimize multiple outbreaks and the H1N1 2009 pandemic of the past decade. Though transmission via a maritime port is one of many potential scenarios and less likely than via air travel, it illustrates the potential for federal Cabinet departments, agencies, and their partners to collaborate heterarchically. The federal government must not only develop, but also maintain such a heterarchy to ensure public safety and improve the nation's security against all future pandemic threats.

\section{Notes}

1. Zoonotic diseases are those that can be transmitted from animals to humans.

2. Morbidity refers to the rate of the incidence of disease in a population. Mortality refers to the rate of the incidence of death or the number of deaths in a population (http:// www.diffen.com/difference/Morbidity_vs_Mortality).

3. The US response to the $2009 \mathrm{H} 1 \mathrm{~N} 1$ pandemic cost $\$ 6.15$ billion (GAO 2011). Billions have additionally been spent on investing in, developing, and approving vaccines (GAO 2011; White House 2007). There are assumptions and justifications: the US will not be able to depend on obtaining enough vaccines from another country. The entire world's manufacturing capacity for just one influenza vaccine is "limited" at approximately 1,400 million doses per year (Oshitani, Kamigaki, and Suzuki 2008; WHO 2012b), but a shortage will likely occur because the vaccine requires two doses per person (Lemon 2007, 62).

4. The relationship between organizational structure and the capacity to achieve organizational goals has been established in public administration and organizational behavior by Frederick Winslow Taylor, Mary Parker Follett, Chester Barnard, Max Weber, Chris Argyris, and Warren Bennis, among others.

5. CDC has estimated there were as many as 89 million US cases of H1N1 between 2009 and 2010, with 18,300 deaths during that same period (GAO 2011). Portraying this event as lucky underscores the potentially devastating high mortality that pandemics can cause. 
110 - Heterarchy: An Interorganizational Approach to Securing the US Against a Pandemic Threat

Appendix: Countries Affected by Infectious Disease Outbreaks, Epidemics, and

Pandemics, $1997-2013$

\begin{tabular}{|c|c|c|c|c|c|c|c|c|c|c|c|c|c|}
\hline 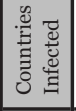 & $\rightarrow$ & -7 & $\sigma$ & $n$ & 0 & ה & ส & $\wedge$ & $\sigma$ & $\infty$ & 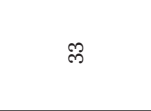 & $a$ & -7 \\
\hline 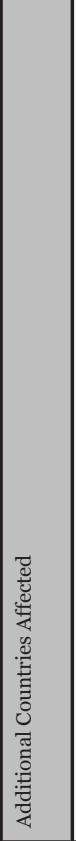 & i & : & 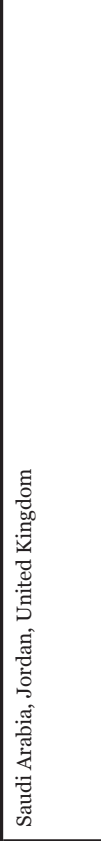 & 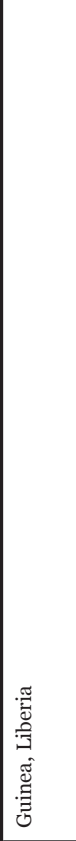 & 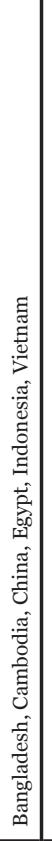 & 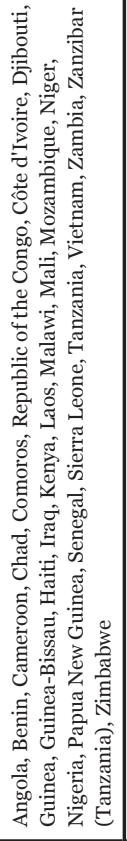 & 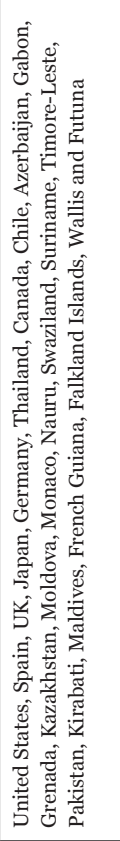 & 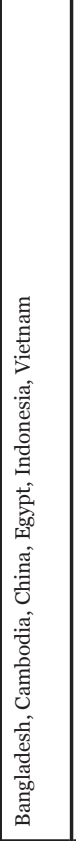 & 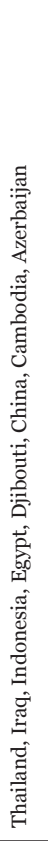 & 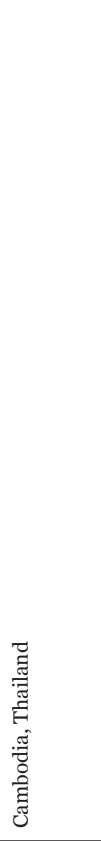 & 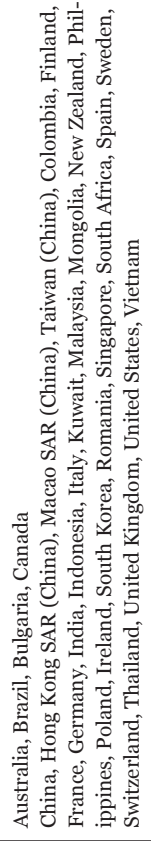 & 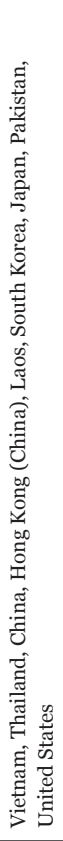 & ; \\
\hline 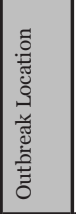 & 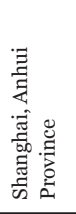 & 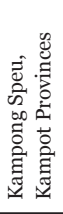 & : & 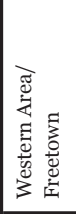 & $:$ & 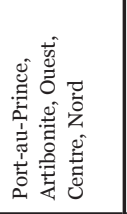 & 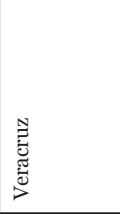 & 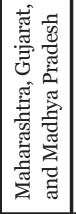 & 焉 & 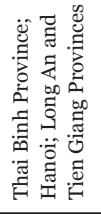 & 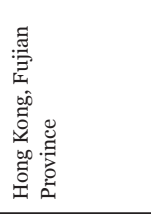 & : & 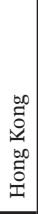 \\
\hline 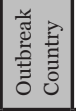 & 苟 & 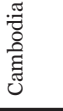 & 惫 & 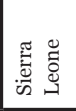 & i & 急 & 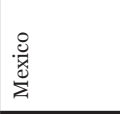 & 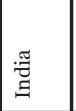 & 苞 & 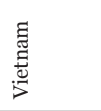 & 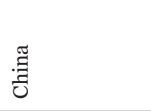 & 苞 & 苟 \\
\hline 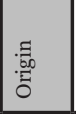 & $\begin{array}{l}\frac{1}{2} \\
\\
0\end{array}$ & $\begin{array}{l}\text { E } \\
\\
\text { a }\end{array}$ & i & 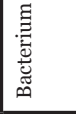 & \begin{tabular}{|l|} 
\\
\\
$\vdots$ \\
2 \\
\end{tabular} & 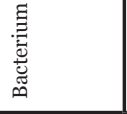 & 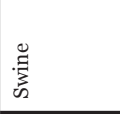 & $\begin{array}{l}\text { E } \\
\\
0 \\
\end{array}$ & $\frac{E}{0}$ & 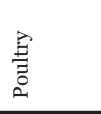 & 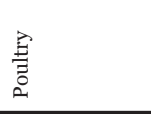 & 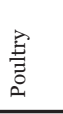 & 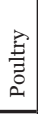 \\
\hline 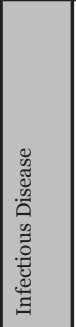 & 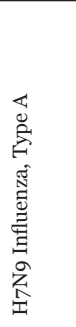 & 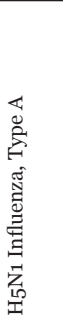 & 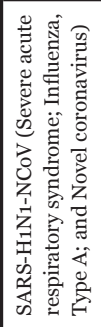 & 要 & $\mid \begin{array}{l}\mid \vec{z} \\
\text { 空 } \\
\end{array}$ & 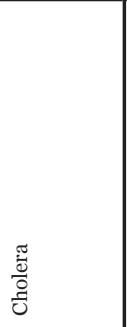 & 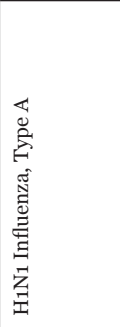 & 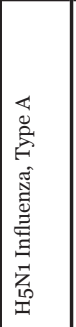 & 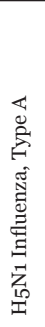 & 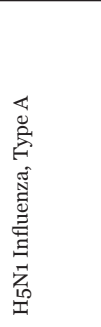 & 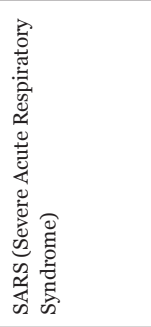 & 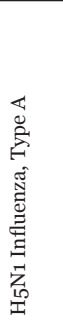 & 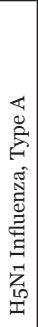 \\
\hline 气̆ & 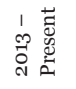 & 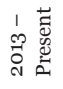 & 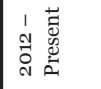 & बें & 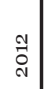 & 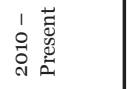 & 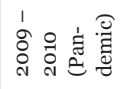 & 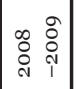 & 品 & 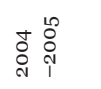 & : & ถั & 命 \\
\hline
\end{tabular}

Source: WHO 2013a, 2013b, 2012a, 2012c, 2012d, 2012e, 2012f, 2012g, 2011a, 2011b, 2010, 2009a, 2009b, 2004, 2003; Honigsbaum 2012; NEJM 2005; CDC 2012a, 2012b, 2013a, 2013b; Chakrabarti 2009; Wikipedia 2013. "Countries" includes territories and semi-autonomous regions. 


\section{References}

Agranoff, Robert and McGuire, Michael. 2004. "Another Look at Bargaining and Negotiating in Intergovernmental Management." Journal of Public Administration Research and Theory 14(4): 495-512.

Altman, Lawrence K. 2009. "Is This a Pandemic? Define 'Pandemic" The New York Times, June 8. http://www.nytimes.com/2009/06/o9/health/o9docs.html.

APHA (American Public Health Association). 2013. "Examples of sequestration impacts on CDC programs.” Accessed March 20, 2013. http://www.apha.org/NR/ rdonlyres/54EF58CC-FE85-48E8-8Fo8-49AC2FA44DC2/o/CDCsequestrationimpacts.pdf.

Burr, Richard. 2013. "Senator Burr Applauds Unanimous Passage of the Pandemic and All-Hazards Preparedness Reauthorization Act of 2013." February 28. http://burr.senate.gov/public/index.cfm?FuseAction=PressOffice. Press Releases \&ContentRecord_id =2217055e-c37f-4540-e654eod1997ed67b\&Region.

California Healthline. 2013. "Obama Signs Order To Cut $\$ 85$ B Under First Part of Budget Sequestration.” March 4. http://www.californiahealthline.org/articles/2013/3/4/obama-signs-order-to-cut-85b-under-first-part-of-budget-sequestration.aspx.

CBO (Congressional Budget Office). 2006. "A Potential Influenza Pandemic: Possible Macroeconomic Effects and Policy Issues.” Revised July 27. http://www.cbo. gov/sites/default/files/cbofiles/ftpdocs/69xx/doc6946/12-o8-birdflu.pdf.

CBP (US Customs and Border Protection). 2013. "Locate a Port Of Entry: Air, Land, or Sea.” Accessed March 20, 2013. http://www.cbp.gov/xp/cgov/toolbox/contacts/ports/.

CDC (Centers for Disease Control and Prevention). 2008. "The Next Flu Pandemic: What to Expect.” October. http://www.flu.gov/planning-preparedness/community/nextflupandemic.pdf.

--—. 2012a. "Highly Pathogenic Avian Influenza A $\left(\mathrm{H}_{5} \mathrm{~N}_{1}\right)$ in People." Last modified June 21, 2012. http://www.cdc.gov/flu/avianflu/h5n1-people.htm.

---. 2012b. Haiti Cholera Outbreak [map]. July 15, 2012. Situation Awareness GIS GRASP. http://www.bt.cdc.gov/situationawareness/haiticholera/Flash/bt/atlas.html (March 5, 2013).

Chakrabarti A.K., Pawar S.D., Cherian S.S., Koratkar S.S., Jadhav S.M., et al. 2009. "Characterization of the Influenza A $\mathrm{H}_{5} \mathrm{N1}$ Viruses of the 2008-09 Outbreaks in India Reveals a Third Introduction and Possible Endemicity.” PLoS One 4: 11.

Cohen, Bryan. 2013. "Senate and House pass PAHPA reauthorization bill." Bio Prep Watch, March 5. http://www.bioprepwatch.com/news/senate-and-housepass-pahpa-reauthorization-bill/327986/.

Considine, Mark and Jenny M. Lewis. 2003. "Bureaucracy, Network, or Enterprise? Comparing Models of Governance in Australia, Britain, the Netherlands, and New Zealand." Public Administration Review 63(2): 131-140. http:// glennschool.osu.edu/faculty/brown/home/Public\%2oManagement/PM\%2O Readings/Considine\%202003.pdf.

-- . 2007. "Innovation and Innovators Inside Government: From Institutions to Networks.” Governance, 20: 581-607. http://onlinelibrary.wiley.com.proxygw. wrlc.org/doi/10.1111/j.1468-0491.2007.00373.x/full.

Cooper, Ben, Richard J. Pitman, W. John Edmunds, Nigel J. Gay. 2006. “Delaying the International Spread of Pandemic Influenza.” PLOS Medicine 3: 12. http:// 
www.plosmedicine.org/article/info:doi/10.1371/journal.pmed.0030212.

Crumley, Carole L. 1995. "Heterarchy and the Analysis of Complex Societies." Archeological Papers of the American Anthropological Association, 6: 1-5. Accessed http://www.sonoma.edu/users/p/purser/Anth59o/crumley\%2oheterarchy. pdf.

Dawson, Ross. 2009. "Heterarchy: Technology, Trust and Culture.” People and Strategy 32(1): 13. http://www.rossdawsonblog.com/HRPS_Heterarchy.pdf.

Denlinger, Rebecca, Martha Marsh, and Bruce Rodhe. 2007. "The Prioritization of Critical Infrastructure for a Pandemic Outbreak in the United States Working Group: Final Report and Recommendations by the Council.” National Infrastructure Advisory Council, January 16. http://www.dhs.gov/xlibrary/assets/ niac/niac-pandemic-wg_v8-011707.pdf.

DHS (US Department of Homeland Security). 2013a. "Homeland Security Information Network.” Accessed March 17, 2013. http://www.dhs.gov/homeland-securityinformation-network.

-_-. 2013b. "Creation of the Department of Homeland Security." Accessed March 17, 2013. http://www.dhs.gov/creation-department-homeland-security.

DTIC (Defense Technical Information Center). 2012. "Chemical, Biological, Radiological, and Nuclear Consequence Management.” Joint Publication 3-41. June 21. http://www.dtic.mil/doctrine/new_pubs/jp3_41.pdf.

ESRI. 2013. "Glossaries." Accessed March 9. http://www.esri.com/what-is-gis/overview\#glossaries_panel.

FEMA (Federal Emergency Management Agency) 2012. "National Preparedness Report." March 30. http://www.fema.gov/library/viewRecord.do?id=5914.

Food Safety News. 2013. "CDC Cut of \$450 Million Will Likely Come at a Greater Cost." March 5. http://www.foodsafetynews.com/2013/o3/cdc-cuts-unlikely-to-savemore-than-they-will-cost/\#.UTWOTnyDQXw.

GAO (US Government Accountability Office). 2011. "Lessons from the H1N1 Pandemic Should Be Incorporated into Future Planning.” GAO-11-632, June 27. http:// www.gao.gov/products/GAO-11-632.

---. 2008. "HHS and DHS Should Further Strengthen Their Ability to Respond to TB Incidents.” GAO-09-58, October 14. http://www.gao.gov/products/GAO09-58.

Heinrich, Janet. 2004. "Infectious Disease Preparedness: Federal Challenges in Responding to Influenza Outbreaks." Testimony Before the Special Committee on Aging, US Senate. September 28. http://www.gao.gov/new.items/do4110ot. pdf.

Hellingrath, Bernd and Peer Küppers. 2011. "Multi-Agent Based Collaborative Demand and Capacity Network Planning in Heterarchical Supply Chains.” Association for the Advancement of Artificial Intelligence Proceedings. http://www.sfbtr8. spatial-cognition.de/ailog-2011/ailog-downloads/2011/paper_15.pdf.

HHS (US Department of Health and Human Services). 2012. "An HHS Retrospective on the 2009 H1N1 Influenza Pandemic to Advance All Hazards Preparedness." Revised June 15, 2012. http://www.phe.gov/Preparedness/mcm/h1n1-retrospective/Documents/h1n1-retrospective.pdf.

- - . 2013. "Assistant Secretary Nicole Lurie statement on the Pandemic and All Hazards Preparedness Reauthorization Act.” Press release. March 13, 2013. http:// www.hhs.gov/news/press/2013pres/o3/20130313a.html.

-_-. n.d. "Supplement 4: Infection Control." Table of Contents. Accessed March 22, 2012. http://www.hhs.gov/pandemicflu/plan/pdf/So4.pdf. 
HHS and DHS (US Department of Health and Human Services and US Department of Homeland Security). n.d. "Guidance on Allocating and Targeting Pandemic Influenza Vaccine.” Accessed March 2, 2013. http://www.flu.gov/images/reports/pi_vaccine_allocation_guidance.pdf.

Honigsbaum, Mark. 2012. "How pandemics spread." [video]. TEDEducation, March 11, 2012. http://ed.ted.com/lessons/how-pandemics-spread.

HSC (US Homeland Security Council). 2005. "National Strategy for Pandemic Influenza.” http://www.flu.gov/planning-preparedness/federal/pandemic-influenza. pdf.

-- . 2006. "National Strategy for Pandemic Influenza: Implementation Plan.” http:// www.flu.gov/planning-preparedness/federal/pandemic-influenza-implementation.pdf.

- - . 2007. "National Strategy for Pandemic Influenza: Implementation Plan. One Year Summary." https://www.premierinc.com/safety/topics/influenza/downloads/whitehouse-pandemic-flu-oneyear.pdf.

ILRI (International Livestock Research Institute). 2012. "Mapping of Poverty and Likely Zoonoses Hotspots.” Zoonoses Project 4, June 18. http://www.dfid.gov.uk/r4d/ pdf/outputs/livestock/ZooMapDFIDreport18June2012FINALsm.pdf.

Jenkins, William O. 2006. "Collaboration over Adaptation: The Case for Interoperable Communications in Homeland Security.” Public Administration Review 66(3): $319-321$.

Kamarck, E. C. 2002. "Applying 21st-Century Government to the Challenge of Homeland Security." PricewaterhouseCoopers Endowment for the Business of Government. http://www.hks.harvard.edu/m-rcbg/research/e.kamarck_pricewaterhouse_applying.21st.century.government.pdf.

Kettl, Donald. 2008. The Next Government of the United States: Why Our Institutions Fail Us and How to Fix Them. New York, NY: W. W. Norton \& Company, 2008.

---. 2006. "Managing Boundaries in American Administration: The Collaboration Imperative." Public Administration Review 64(s1): 10-19.

Kleiner, Art. 2009. "Heterarchies: Human Nature Transformed?” People and Strategy 32(1): 12-13. http://search.proquest.com.proxygw.wrlc.org/ docview/224586248/fulltextPDF?accountid=11243.

Lemon, Stanley M., Margaret A. Hamburg, P. Frederick Sparling, et al. 2007. "Ethical and Legal Considerations in Mitigating Pandemic Disease: Workshop Summary." Forum, Institute of Medicine. http://www. .nlm.nih.gov/books/NBK54167/ pdf/TOC.pdf.

Mahler, Julianne, and Maureen Hogan Casamayou. 2009. Organizational Learning at NASA: The Challenger and Columbian Accidents. Washington, DC: Georgetown University Press.

McCulloch, Warren S. 1945. "A Heterarchy of Values Determined by the Topology of Nervous Nets.” Bull. Math. Biophysics 7: 89-93. http://www.vordenker.de/ ggphilosophy/mcculloch_heterarchy.pdf.

McGuire, Michael. 2006. "Collaborative Public Management: Assessing What We Know and How We Know It." Public Administration Review 66(s1): 33-43.

Meeks, Brock N. 2005. "Homeland Security to be lead in flu crisis: But DHS will defer all medical response to Health and Human Services.” NBC News, October 11. http://www.nbcnews.com/id/9654456/\#.URqofaXnWSo.

Milward, H. Brinton, and Keith G. Provan. 2006. A Manager's Guide to Using and Choosing Collaborative Networks. Washington, DC: IBM Report on the Business of Government. 
Monke, Jim. 2005. "The Virus-Serum-Toxin Act: A Brief History and Analysis.” Congressional Research Service. January 3. http://www.nationalaglawcenter.org/ assets/crs/RS22014.pdf.

Mosquera, Mary. 2006. "DHS to Develop Biosurveillance System for Pandemic." GCN, May 12. http://gcn.com/articles/2006/05/12/dhs-to-develop-biosurveillancesystem-for-pandemic.aspx.

Napolitano, Janet. 2009. "Remarks by Secretary Napolitano at the H1N1 Influenza Summit.” http://www.dhs.gov/news/2009/07/10/secretary-napolitanos-remarksh1n1-influenza-preparedness-summit.

NEJM (New England Journal of Medicine). 2005. “Avian Influenza A ( $\left.\mathrm{H}_{5} \mathrm{~N} 1\right)$ Infection in Humans.” http://www.nejm.org/doi/full/10.1056/NEJMra052211.

Oshitani, Hitoshi, Taro Kamigaki, and Akira Suzuki. 2008. Major Issues and Challenges of Influenza Pandemic Preparedness in Developing Countries. Emerging Infectious Diseases 14(6): 875-880.

O’Toole, Laurence J. Jr. and Kenneth J. Meier. 2004. "Public Management in Intergovernmental Networks: Matching Structural and Behavioral Networks.” Journal of Public Administration Research and Theory 14:469-94.

O’Toole, Laurence J. Jr. 1997. "Treating Networks Seriously: Practical and ResearchBased Agendas in Public Administration.” Public Administration Review 57(1): 45-52. http://www.jstor.org/discover/10.2307/976691?uid=3739584\&uid=2 \&uid $=4 \&$ uid $=3739256 \&$ sid $=21101867070101$.

Pascoe, N. 2006. "A Pandemic Flu: Not If, But When. SARS Was the Wake-up call We Slept Through.” National Center for Biotechnology Information.

Pavgi, Kedar. 2012. "Agencies need better plans to protect feds in a flu pandemic, GAO says.” GovExec, August 3. http://www.govexec.com/oversight/2012/o8/agencies-need-better-plans-protect-feds-flu-pandemic/57223/.

PR Newswire. 2005. "Defense and Intelligence Needs Drive Federal Organizations to Adopt Wireless Mesh Networks.” October 20. http://search.proquest.com/doc view/451338807?accountid=11243.

Reus, Bas. 2009. "Bas Reus' quest on self-organization and online collaborative spaces: Heterarchies.” http://basreus.nl/2009/10/o1/heterarchies/.

Reuters. 2009. "WHO revises scale for pandemic alerts." April 27. http://www.reuters. com/article/2009/04/27/us-flu-who-revised-idUSTRE53Q60320090427.

Rodrigue, Jean-Paul, Thomas Luke, and Michael Osterholm. 2013. "Transportation and Pandemics.” Hofstra University, New York. Accessed February 27, 2013. http:// people.hofstra.edu/geotrans/eng/ch9en/applgen/ch9a3en.html.

Senge, Peter. 2006. The Fifth Discipline. New York: Currency/Doubleday.

Stark, David. 2001. "Heterarchy: Exploiting Ambiguity and Organizing Diversity." Brazilian Journal of Political Economy 21(1): 81. http://www.rep.org.br/pdf/81-2. pdf.

Stephenson. Karen. 2009. "Neither Hierarchy nor Network: An Argument for Heterarchy." People and Strategy 32(1): 4-7.

Stojanovic, Nenad and Alexander Artikis. 2011. "On Complex Event Processing for RealTime Situational Awareness.” Rule-Based Reasoning, Programming, and Applications, Lecture Notes in Computer Science 6826: 114-121. Accessed April 3, 2013. http://download.springer.com/static/pdf/459/chp\%253A10.1007\%2 52F978-3-642-22546-8_10.pdf?auth66=1361208255_o01ac21b38e9ab3b6817 a2eeo23bcfid\&ext=.pdf.

Schwartz, Rachel D. and Jonathan Schwartz. 2010. "Confronting Global Pandemics: Lessons from China and the US.” http://ghgj.org/Schwartz\%20and\%20 
Schwartz_Confronting\%20Global\%20Pandemics.pdf.

Tatem, A.J., D.J. Rogers, and S.I. Hay. 2006. "Global Transport Networks and Infectious Disease Spread.” Advances in Parsitology 62: 293-343.

USAID (US Agency for International Development). 2013. "Emerging Pandemic Threats Program.” Last updated March 28. Accessed April 1, 2013. http://www.usaid. gov/news-information/fact-sheets/emerging-pandemic-threats-program.

USCG (US Coast Guard). 2011a. "Missions.” Accessed February 29, 2012. http://www. uscg.mil/top/missions.

-—-. 2011b. "Frequently Asked Questions.” Accessed February 29, 2012. http://www. uscg.mil/top/about.

-—-. 2011c. "Alien Migrant Interdiction.” Accessed February 19, 2012. http://www. uscg.mil/hq/cg5/cg531/AMIO/amio.asp.

- - . 2011d. "Alien Migrant Interdiction: Total Interdictions - Fiscal Year 1982 to Present.” Accessed February 19, 2012. http://www.uscg.mil/hq/cg5/cg531/AMIO/ FlowStats/FY.asp.

-- . 2010. "US Coast Guard: America's Maritime Guardian.” Accessed March 18, 2013. http://www.uscg.mil/d17/sectJuneau/docs/Coast\%2oGuard\%2opowerpoint.ppt.

US Congress. 2013. H.R.307. "Pandemic and All-Hazards Preparedness Reauthorization Act of 2013." http://beta.congress.gov/bill/113th-congress/house-bill/307.

USDA (US Food and Drug Administration). 2006. "USDA, DOI and HHS Expand Screening for Highly Pathogenic $\mathrm{H}_{5} \mathrm{~N}_{1}$ Avian Influenza in Migratory Birds.” March 20. http://www.usda.gov/wps/portal/usda/usdahome?contentidonly= true\&contentid=2006/03/0095.xml.

Wachhaus, T. A. 2008. "Networks in contemporary public administration: A discourse analysis." The Pennsylvania State University. Accessed February 13, 2013. http://search.proquest.com/docview/304508100?accountid=11243.

Wasem, Ruth Ellen. 2011a. "Immigration Policies and Issues on Health-Related Grounds for Exclusion.” Congressional Research Service. January 6. http://www.fas. org/sgp/crs/homesec/R40570.pdf.

-_-. 2011b. "US Immigration Policy on Haitian Migrants." Congressional Research Service. May 17, 2011. http://www.fas.org/sgp/crs/row/RS21349.pdf.

White House. 2012. "National Strategy for Biosurveillance." July 31. http://www. whitehouse.gov/sites/default/files/National_Strategy_for_Biosurveillance_ July_2012.pdf.

-—-. 2007. Archives. http://georgewbush-whitehouse.archives.gov/infocus/pandemicflu/.

- - . 2005. "National Strategy for Pandemic Influenza.” Archives. http://georgewbushwhitehouse.archives.gov/homeland/pandemic-influenza.html.

WHO (World Health Organization). 2013a. Alert. February 1, 2013. http://www.who. int/csr/don/2013_02_01/en/index.html.

--—. 2013b. "H7N9 avian influenza human infections in China." Accessed April 2, 2013. http://www.who.int/csr/don/2013_04_01/en/index.html.

--—. 2012a. "H5N1 avian influenza: Timeline of major events." January 25, 2012. http://www.who.int/influenza/human_animal_interface/H5N1_avian_influenza_update.pdf.

---. 2012b. Executive Board Agenda. November 16, 2012. Dr. Margaret Chan. "Pandemic influenza preparedness: sharing of influenza viruses and access to vaccines and other benefits." http://apps.who.int/gb/ebwha/pdf_files/EB132/ B132_16-en.pdf. 
--—. 2012c. Cholera in Sierra Leone and Guinea (Situation as of 01 September 2012). http://www.afro.who.int/en/clusters-a-programmes/dpc/epidemic-a-pandemic-alert-and-response/outbreak-news/3683-cholera-in-sierra-leone-andguinea-situation-as-of-o1-september-2012.html.

-—-. 2012d. Cholera in Sierra Leone - update. http://www.who.int/csr/ don/2012_09_o8/en/index.html.

-—-. 2012e. Cholera. http://www.who.int/mediacentre/factsheets/fs107/en/index. html.

- - . 2012f. Areas affected by cholera epidemics. http://www.who.int/gho/epidemic diseases/cholera/epidemics_text/en/index.html.

-—-. 2012g. Cholera Country Profiles. http://www.who.int/cholera/countries/en/index.html.

---. 2011a. Avian influenza fact sheet. April 2011. http://www.who.int/mediacentre/ factsheets/avian_influenza/en/index.html.

-- . 2011b. Cholera outbreaks in the Democratic Republic of Congo (DRC) and the Republic of Congo. http://www.who.int/csr/don/2011_07_22/en/index.html.

-—-. 2011c. "Shared nomenclature." October 18, 2011. Accessed February 18, 2013. http://www.who.int/influenza/gisrs_laboratory/terminology_ah1n1pdmo9/ en/index.html.

---. 2010a. Statement. H1N1 in post-pandemic period. http://www.who.int/mediacentre/news/statements/2010/h1n1_vpc_20100810/en/index.html.

- - . 2010b. Cholera in Central Africa. http://www.who.int/csr/don/2010_10_o8/ en/index.html.

--—. 2009a. Pandemic (H1N1) 2009 - update 6o. http://www.who.int/csr/ don/2009_08_04/en/index.html.

-—- 2009b. Pandemic (H1N1) 2009 - update 61. http://www.who.int/csr/ don/2009_08_12/en/index.html.

- - . 2003. Update 28 - Affected areas, status of SARS outbreaks in individual countries. http://www.who.int/csr/sarsarchive/2003_04_12/en/.

-—-. 2004. $\mathrm{H}_{5} \mathrm{~N} 1$ avian influenza: a chronology of key events. http://www.who.int/ influenza/resources/documents/chronology/en/index.html.

- - - n.d. "The control of neglected zoonotic diseases." Accessed March 15, 2013. http://www.who.int/zoonoses/control_neglected_zoonoses/en/index.html.

Wikipedia. 2013. "Global Spread of $\mathrm{H}_{5} \mathrm{N1}$." Revised March 2O, 2013. Accessed March 25, 2013. http://en.wikipedia.org/wiki/Global_spread_of_H5N1.

Yu, Genong, Liping Di, J.A. Smith, Bei Zhang, Peichuan Li, Hulin Wang, Min Min. 2009. "Sensor Web Service Integration for Pandemic Disease Spread Simulation." Geoinformatics, 17th International Conference Publication: 1-6. http://ieeexplore.ieee.org.proxygw.wrlc.org/stamp/stamp.jsp?tp=\&arnumber $=5293497$. 
Diane Mars is a Master of Public Administration candidate (expected 2013) concentrating in federal management at The George Washington University. She serves as Shortterm Consultant at The World Bank. Diane has eight years of experience executing projects and initiatives, most recently at Deloitte's Federal Practice and service nonprofits, and previously at academic publishers and legal institutiowns. She earned a BA in English from the University of California, Berkeley. Outside of school and work, Diane enjoys perambulations, dog-watching, and corny jokes.

The author thanks Dr. Kathryn Newcomer and Anne Berry for their editorial guidance. She would also like to thank Kristin Hubing, Julia Watts, and Dr. Ron Carlee for their support, as well as Eric Boyer and Adm. Thad Allen for their roles in prompting the article's earliest draft. Finally, she thanks her family and David Wertime for encouragement and inspiration. 